This is an electronic reprint of the original article. This reprint may differ from the original in pagination and typographic detail.

Author(s): Kyppö, Anna; Natri, Teija

Title: $\quad$ Promoting multilingual communicative competence through multimodal academic learning situations

Year: $\quad 2016$

Version:

Please cite the original version:

Kyppö, A., \& Natri, T. (2016). Promoting multilingual communicative competence through multimodal academic learning situations. In S. Papadima-Sophocleous, L. Bradley, \& S. Thouësny (Eds.), CALL communities and culture - short papers from EUROCALL 2016 (pp. 243-247). Research-publishing.net.

https://doi.org/10.14705/rpnet.2016.eurocall2016.569

All material supplied via JYX is protected by copyright and other intellectual property rights, and duplication or sale of all or part of any of the repository collections is not permitted, except that material may be duplicated by you for your research use or educational purposes in electronic or print form. You must obtain permission for any other use. Electronic or print copies may not be offered, whether for sale or otherwise to anyone who is not an authorised user. 


\title{
Promoting multilingual communicative competence through multimodal academic learning situations
}

\author{
Anna Kyppö ${ }^{1}$ and Teija Natri ${ }^{2}$
}

\begin{abstract}
This paper presents information on the factors affecting the development of multilingual and multicultural communicative competence in interactive multimodal learning environments in an academic context. The interdisciplinary course in multilingual interaction offered at the University of Jyväskylä aims to enhance students' competence in multilingual and multicultural academic communication by promoting the use of their entire linguistic repertoire in various learning situations. Throughout the course, we observed the students' engagement in multilingual and multicultural activities. These observations suggest that simultaneous use of multiple languages in synchronous and asynchronous learning environments has evident impact on the development of learners' multilingual and multicultural competences as well as increases their multicultural awareness. Learners' experiences, collected through learning journals and reflective feedback, suggest that the use of multimodal interactive learning environments may support multilingual and multicultural learning and enhance learner agency.
\end{abstract}

Keywords: multilingual communication, multicultural communication, multilingual and multicultural academic communication competence, multicultural awareness, learner agency.

\section{Introduction}

This empirical study presents information about affordances for the development of learners' multilingual and multicultural communicative competence in interactive multimodal learning environments. The context of the study is an interdisciplinary course in multilingual interaction aimed at enhancing students' competence in multilingual and multicultural academic communication by promoting the use

1. University of Jyväskylä, Jyväskylä, Finland; anna.kyppo@jyu.fi

2. University of Jyväskylä, Jyväskylä, Finland; teija.natri@jyu.fi

How to cite this article: Kyppö. A., \& Natri, T. (2016). Promoting multilingual communicative competence through multimodal academic learning situations. In S. Papadima-Sophocleous, L. Bradley \& S. Thouësny (Eds), CALL communities and culture - short papers from EUROCALL 2016 (pp. 243-247). Dublin: Research-publishing.net. https://doi.org/10.14705/ rpnet.2016.eurocall2016.569 
of their entire linguistic repertoire in various social learning situations. A major source of inspiration is the MAGICC project of the EU Lifelong Learning Programme 2012-2014 (http://www.magicc.eu), which emphasises the role of languages and communication as part of academic expertise. Of similar importance is Blommaert's (2010) perception of multilingualism as a complex of semiotic resources and a repertoire of varying language abilities. The focus is on various aspects of multilingual and multicultural communication. Due to the multilingual character of the course, students are required to have partial competence in at least two languages other than their L1. Furthermore, the presence of four to five teachers with various linguistic repertoires facilitates the creation of multilingual social space. To enhance learner agency and increase learners' multilingual agility, task-based learning is employed. Multiple languages in synchronous and asynchronous learning environments are used simultaneously, an approach which results in multidirectional teacher-learner interaction and the enhancement of multicultural skills.

\section{Method}

Even though the concepts of multilingualism and multilingual competence have been explored from various perspectives, our focus is on learning. Our theoretical background, therefore, is to be found in Blommaert's (2010) definition on multilingualism (see above) and in theories related to translanguaging (Garcia, 2009; Park, 2013; Swain \& Watanabe, 2012). The purpose is to promote the development of learners' multilingual communicative competence through multilingual mediation and meaning-making. Learners' multilingual repertoires are activated through various interactive scenarios. In these they are expected to employ their problem-based learning strategies to find a solution or to act in a situation that is close to real life. The lessons are in line with scenario-based e-learning (Pappas, 2014), which gets learners involved in 'real-life simulations' and provides them with learning experiences aimed at gathering skills which may be useful for their future working life. Through the lessons, various aspects of multilingual and multicultural communication are addressed, including non-verbal communication, various mediation activities such as intercomprehension, activation of receptive skills between typologically related yet different languages (Berthele, 2007), and persuasion and negotiation in multicultural settings. In mediation activities, one or more languages are used for reading or listening and one or more other languages for speaking or writing. To enhance learners' collaborative social skills, the educational mobile platform REAL, developed by the Jyväskylä University of Applied Sciences, is used in scenario-based assignments, while the web-based learning platform Optima serves as the course 
workspace. Optima further acts as a uniting factor facilitating the common learning experience. Learner logs have been used to obtain information on the usefulness of tasks, technology choices and the achievement of learning outcomes. In addition, a final survey on learner agency - on their commitment to and engagement in the learning process (Mercer, 2012) - was conducted.

\section{Discussion}

The course aim was to activate learners' overall linguistic repertoires. Students found that the course helped to develop their linguistic agility and viewed it as a safe learning environment in which to share their ideas on various aspects of linguistic and cultural identity.

"this class gave an important opportunity to reflect upon my recent and notso-recent experiences in multilingual and multicultural environments... I had the chance to make sense and understand on a deeper level some of the things that I had encountered in the real world. Also, this class helped to break the barriers we tend to build between languages. It helped me understand that my language skills reach over the boundaries of languages, I understand and speak languages that I don't officially understand or speak. That is an important discovery that everyone should get the chance to make already in high school, for example" (Student learner log, unedited).

The feedback on the task design and use of the mobile platform received from students' learner logs and course feedback forms was very significant, especially for the teachers. The mobile platform REAL was tested in scenarios related to the concept of culture and receptive multilingualism. The tasks consisted of communicative assignments, such as searching for information, negotiation and decision-making. Students were obviously not only aware of the raison d'être of scenarios, but they were also excited by the use of this particular platform due to its flexibility and the user-friendly mobile application.

"This app [REAL] is innovative, functioning... it enables sharing the ideas... The chat is quick and dynamic, and what is best, it is accessible from more than one device. It is near to us, young people's lifestyle, since we master the technology..." (Student learner log, unedited).

Students felt that they were free to express their opinions via REAL and preserve their privacy at the same time. Voting and commenting was considered to be attractive and 
to increase participants' engagement in discussions. From the teachers' viewpoint, the use of new technology offers not only a unique opportunity to document the flow of discussion, but also the possibility to pinpoint some ideas or recurrent themes in students' discussions by means of word clouds and other visual tools.

While student reflections and feedback collected through learner logs generally referred to the task design and the use of the mobile platform, the end-of-course survey provided information on students' learner agency, that is, on their activity and initiative as well as their personal engagement in the learning process. According to Mercer (2012), agency reflects not only the learners' attitudes and observable actions, but also their behavior, beliefs, thoughts and feelings, which may not be observable through the feedback and learner logs. The survey reveals that the majority of students took responsibility for shared learning situations and perceived the co-students as a resource for learning. The technological solutions used on the course were regarded as supportive for teamwork. Furthermore, they were perceived as providing a meaningful learning experience.

\section{Conclusions}

As the challenges of international and multicultural working life have increased, the need for multilingual and multicultural courses at the university level has grown. Courses in multilingual and multicultural communication may enhance learner agency and provide students with tools and strategies that will be useful in their professional careers. Furthermore, the integration of multiple languages into subject studies and the use of multimodal interactive online resources are essential because they present an integrated part of people's professional frameworks.

The experiences of learners and teachers collected on this course reveal a range of issues that would be important for further study: interactive multimodal learning environments, which seem to be a major affordance for both parties; the development of multidirectional networking skills and the acquisition of multilingual/multicultural communication competences.

\section{Acknowledgements}

We would like to thank the students and colleagues who have worked with us on the course as well as Peppi Taalas (PhD), Language Centre Director, who has 
paved the way for the development of multilingual and multicultural teaching at the University of Jyväskylä.

\section{References}

Berthele, R. (2007). Zum Prozess des Verstehens und Erschließens. In B. Hufeisen \& N. Marx (Eds), EuroComGerm-Die sieben Siebe: Germanische Sprachen lesen lernen (pp. 15-26). Aachen, Germany: Shaker Verlag

Blommaert, J. (2010). The sociolinguistics of globalization. Cambridge: Cambridge University Press. https://doi.org/10.1017/CBO9780511845307

Garcia, O. (2009). Bilingual education in the 21st century: a global perspective. Oxford: WileyBlackwell.

Mercer, S. (2012). The complexity of learner agency. Apples - Journal of Applied Language Studies, 6, 41-59.

Pappas, C. (2014). Scenario-based e-learning to improve learners' engagement [Blog post]. https:/elearningindustry.com/the-basics-of-scenario-based-e-learning

Park, M. S. (2013). Code-switching and translanguaging: potential functions in multilingual classroom. Working Papers in TESOL \& Applied linguistics, 13(2), 50-52.

Swain, M., \& Watanabe, Y. (2012). Languaging: collaborative dialogue as a source of second language learning. In C. Chapelle (Ed.), The encyclopedia of applied linguistics. Oxford: Blackwell Publishing. https://doi.org/10.1002/9781405198431.wbeal0664 


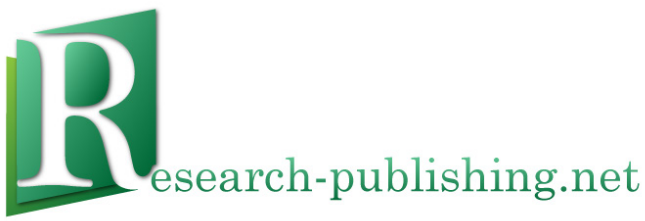

Published by Research-publishing.net, not-for-profit association Dublin, Ireland; Voillans, France, info@research-publishing.net

(C) 2016 by Editors (collective work)

(C) 2016 by Authors (individual work)

\section{CALL communities and culture - short papers from EUROCALL 2016 Edited by Salomi Papadima-Sophocleous, Linda Bradley, and Sylvie Thouësny}

Rights: All articles in this collection are published under the Attribution-NonCommercial -NoDerivatives 4.0 International (CC BY-NC-ND 4.0) licence. Under this licence, the contents are freely available online as PDF files (https://doi. org/10.14705/rpnet.2016.EUROCALL2016.9781908416445) for anybody to read, download, copy, and redistribute provided that the author(s), editorial team, and publisher are properly cited. Commercial use and derivative works are, however, not permitted.

\section{(9) $\Theta \Theta$}

Disclaimer: Research-publishing.net does not take any responsibility for the content of the pages written by the authors of this book. The authors have recognised that the work described was not published before, or that it is not under consideration for publication elsewhere. While the information in this book are believed to be true and accurate on the date of its going to press, neither the editorial team, nor the publisher can accept any legal responsibility for any errors or omissions that may be made. The publisher makes no warranty, expressed or implied, with respect to the material contained herein. While Research-publishing.net is committed to publishing works of integrity, the words are the authors' alone.

Trademark notice: product or corporate names may be trademarks or registered trademarks, and are used only for identification and explanation without intent to infringe.

Copyrighted material: every effort has been made by the editorial team to trace copyright holders and to obtain their permission for the use of copyrighted material in this book. In the event of errors or omissions, please notify the publisher of any corrections that will need to be incorporated in future editions of this book.

Typeset by Research-publishing.net

Cover design by (C) Easy Conferences, info@easyconferences.eu,www.easyconferences.eu

Cover layout by (c) Raphaël Savina (raphael@savina.net)

Photo "bridge" on cover by (C) Andriy Markov/Shutterstock

Photo "frog" on cover by (C) Fany Savina (fany.savina@gmail.com)

Fonts used are licensed under a SIL Open Font License

ISBN13: 978-1-908416-43-8 (Paperback - Print on demand, black and white)

Print on demand technology is a high-quality, innovative and ecological printing method; with which the book is never 'out of stock' or 'out of print'.

ISBN13: 978-1-908416-44-5 (Ebook, PDF, colour)

ISBN13: 978-1-908416-45-2 (Ebook, EPUB, colour)

Legal deposit, Ireland: The National Library of Ireland, The Library of Trinity College, The Library of the University of Limerick, The Library of Dublin City University, The Library of NUI Cork, The Library of NUI Maynooth, The Library of University College Dublin, The Library of NUI Galway.

Legal deposit, United Kingdom: The British Library.

British Library Cataloguing-in-Publication Data.

A cataloguing record for this book is available from the British Library.

Legal deposit, France: Bibliothèque Nationale de France - Dépôt légal: décembre 2016. 